\title{
THE USE OF BOARD RACE GAME IN IMPROVING STUDENTS' VOCABULARY MASTERY AT SECOND GRADE OF TSANAWIYAH BABUL KHAER BULUKUMBA
}

\author{
Widya Rizky Pratiwi ${ }^{1 *}$, Muhammad Agus Nur ${ }^{1}$ \\ ${ }^{1}$ STMIK Bina Adinata, Jl. Serikaya No 8, Bulukumba 92511, Sulawesi Selatan, \\ Indonesia \\ Correspondent Email pratiwiwidyarizky@gmail.com
}

\begin{abstract}
Vocabulary is the heart of a language because it involves the basic building of English sentences. Without a meaningful vocabulary, the four basic skills of language namely speaking, listening, reading, and writing would never be complete. As vocabulary is the principal issue for English learning, this current research was conducted to see the effectiveness of the Board Race Game to improve the students' mastery of vocabulary. The research was conducted in Tsanawiyah Babul Khaer, Bulukumba. There were 30 students of the second grade in the academic year 2018/2019 who participated in this study which was selected through purposive sampling. In collecting the data, the researchers used the pre and post design of the experimental group. The researchers analyzed the average score of each test to find out the increase in students' vocabulary mastery after the action was conducted. After the researchers have treated the game in four meetings, the students' vocabulary mastery has increased significantly. It could be seen from the score of pre-test was 30,46 and the posttest was 78,2 where the gain of both tests was 47,73. After applying the action, the researchers were able to solve the problem in increasing students' vocabulary mastery. Thus, because of this kinesthetic game was successfully to create a fun atmosphere in the teaching and learning process and increase the students' mastery of vocabulary, it is suggested to use board race game as the alternative media in teaching English.
\end{abstract}

Keywords: Kinesthetic game; Fun atmosphere; increase; Vocabulary; English Teaching.

\section{INTRODUCTION}

Vocabulary is one of the important factors in language teaching; students must continue to learn words when they learn the structure and when they practice the sound system (Syamsinar, Bisse \& Syamsu, 2019). However, Sara (2018) states that vocabulary is not an easy aspect to master in learning a foreign language because of the different interpretations of the words which may cause many problems for learners. 
One of the possible causes of student vocabulary weakness is that teachers still use traditional English teaching methods, as well as in teaching vocabulary. Some teachers only explain the material and then they exercise and train the students to use it in writing skills. The teaching media are only based on textbooks and whiteboards. When the teachers apply this conventional method, the students only sit, listen and passively receive the explanation. It can be imagined how this lesson will be boring and make students feel sleepy when it is taught in the last session.

The case was experienced by the students in some of Junior High School in Indonesia, as well as in Tsanawiyah babul Khaer Bulukumba. Researchers found some students were less interested in learning English. According to the preliminary study by observation and casual talk with the students, one of the demotivational factors in learning English reveals by them was the lack of vocabulary mastery. And it resulted in the students tend to speak in front of other students because they felt embarrassed and afraid to make mistakes in saying words.

The students do not have enough vocabulary because of the teachers implement the same and monotone teaching method. They are diligent to attend the class. They are busy and talk too much in class. However, it is not efficient. Because what the students need is not how to see the teachers speak more in class to show that they master the material well. The students need encouragement on how to love English and learn this language with fun. They need some strategies on how to be easy to memorize the vocabulary as we know that it is a common language in controlled the languages. This is the basic thing should be completed before learning the other skills. Vocabulary is a core component of language skills and provides a basis for how proficient students speak, listen, read and write.

Considering the above case, the researchers tried to use a game to make students enjoy first with this lesson. The students will be more motivated if they having fun doing it (Ma'arif). By games, students can learn vocabulary while playing. And then to ignite student enthusiasm, we thought to race the students and award them who can memorize more vocabulary through Board Race game. This fun game is a game that uses a system of competition between teams with each other.

Therefore, by conducting this race board game, the researchers expected this way will become one of the solution to increase the students' mastery of vocabulary in the second grade of Tsanawiyah babul Khaer.

\section{REVIEW LITERATURE}

\section{The Concept of Vocabulary}

There are many experts who provide definitions of vocabulary with a different word but they have the same meaning. One of them is Soedjito (2009: 24) which is found in Syamsinar, Bisse, and Syamsu (2019). He defines vocabulary in 4 points namely: 1). All words contained in the language, 2). The wealth of words owned by a speaker or writer, 3). Words used in the field of science, and 4). List of words arranged like a dictionary and brief and practical explanations 
Syamsinar, Bisse and Syamsu (2019). In addition, Young (2019) argues that vocabularies are the study of 1) the meaning of the words, 2) how the words are used, 3) root words, prefixes, suffixes, and 4) analogies for comparing two pairs of words and choosing the pair that go together. Vocabulary mastery can be defined as a number of vocabulary (words) in a language that contains information about its meaning, form, and usage in the context of communication. It is the basic knowledge that students should master first before mastering English (Octaviani, Handayani, \& Hamer, 2019).

Vocabulary is the heart of a language (Coady \& Huckin, 1997:5) and this is the basic unit of language. Without vocabulary, no language could produce. The four basic skills of language namely speaking, listening, reading, and writing would never be complete without a meaningful and well-structured vocabulary. So, mastering a target language relies on knowing a number of words (Sara, 2018).

Schmitt (2010) argue "learners carry around dictionaries and not grammar books" (p. 4). It means that even without grammar, with some useful and meaningful words and expressions, someone can communicate and understand a conversation with each other; while when someone lacks vocabulary, it means she/ he lacks words. Second language learners understand that the main obstacle that they face in their learning is the lack of knowledge of an adequate amount of words (Sara, 2018). Therefore, it is necessary for them to rely mainly on dictionaries and not grammatical references.

Learning vocabulary is not only memorizing the list of words. However, it is the complicated process that needs the ability to know the words, to recall them at will, spell and use them correctly (Wallace, 1982). Looking at the English is important, so the learning should be based on the right strategy as well as the teaching must be in the appropriate method. Wallace (1982) gives an addition of two principles in teaching vocabulary. Firstly, the teachers should know the aims. They have to select the words that will be given to the students. Secondly, the teachers must decide on what is involved in vocabulary learning, and then pay attention to the quantity of vocabulary to be learned. Teachers have to avoid giving the students too many vocabulary because it will make them confusing. Thus, they should teach vocabulary based on daily activities to make them familiar and easy to use it.

\section{The Concept of Game}

Game is an activity with rules, a goal, and an element of fun (Hadfield, 1998:4 as cited in Sakilah, 2019). The game has a benefit in the learning process which can be used in the process of teaching and learning activities (Octaviani, Handayani, \& Hamer, 2019). Game is not always just the media of icebreaking in teaching, but it can be a media in assessing the material for the students in a class.

Sari (2014) reveals that educational games could be the alternative to do the assessment. Teachers can use some games as their tools to do evaluation and observation for the students. They are effective to improve students' cognitive achievement and stimulate their motivation (Boeker et.al, 2013). The game can 
increase students' encouragement and help reduce their boredom when learning. So, students are motivated to produce as much as possible to get the best results as expected (Tedjasaputra, 2001). He then proposes the benefits of the game are as follows:

1. For the development of the physical aspects in the play, children have the opportunity to engage in activities that involve the movement of the body, this will make the body healthy children and the muscles of the body become stronger.

2. For the development of fine and gross motor aspect children aged 3 months of starting to learn to get a toy was near, it is children learn to coordinate eye movements with his hands, indirectly, children learn to per motor movements. Aspects of gross motor skills can be developed through the motions of playing. One example, at the beginning he was not skilled to run, but with a game of chase, then the child's interest to do so and ended up running.

3. For the development of the social aspects of play can be helpful in learning the communication with fellow friends, in this case, the child learn to express the content of his thoughts and feelings and learn to understand what was said by a friend so that social relationships can exist and children can exchange information.

4. For the development of aspects of emotion and personality, children will have a vote against him on surplus or a shortage so as to assist the formation of self-concept and are expected to have a sense of confidence and selfesteem. Through play, children learn how to behave and conduct to working with her, to be honest, brave, generous, and so forth.

5. For the development of cognition, many basic concepts that children learn through play, without realizing it children begin to learn, for example, to introduce color and size can be used to play fishing activity which consists of an assortment of colors and sizes. This aspect of cognition is defined as the knowledge, creativity, language skills, and memory.

6. To sharpen sharpness sensing aspects relating to sight, hearing, smell, taste, and tactile need to be sharpened so that children become more responsive to things that are taking place in the environment. It is through play, children are expected to be active and critical of the events that appear in the vicinity.

7. For skill sports and dancing physical development as a basis to develop skills in the field of sports and dancing, when the dancing children skillfully perform these activities, he will be more confident, the most important thing is the children loved and happy at the event which will be developed in accordance with interests, talents, and will eventually become a hobby and even a source of livelihood in the future.

According to Klimova (2015:1157), as cited in Sakilah (2019), because the game is a natural means for children to understand the world around them, it should be part and parcel of their learning, including the learning of foreign language. According to Fansury (2017), Media Games can help students develop vocabulary skills. Media Games is very effective to be applied to avoid burnout 
and boredom of students in participating in the learning process. He explains the reason why games have a positive and effective influence on the learning of foreign languages. They are:

1. Games make students involved in the learning process and of course, motivate them;

2. Games encourage creative and spontaneous use of language;

3. Games introduce a change in formal and traditional learning situations;

4. Games create a pleasant stress-free and relaxing atmosphere in a language class;

5. Games subconsciously promote and practice all four basic language skills;

6. Games help the teacher to create contexts in which the language is meaningful and useful;

7. Games decrease and eliminate students' anxiety to speak in front of the others ;

8. Games are student-centered in which teachers become facilitator;

9. Games can promote cooperativeness among students; and

10. Games can connect to a variety of intelligence.

One of the games which are classified as a linguistic and communicative game is board race game.

\section{Board Race Game}

A board race game is one of many games that can be used in teaching-learning activities (Ma'arif). A board game is a game that when we play it, someone throws the dice in the counters and we can step forward based to dice. This board game is a game that involves counters or pieces moved or placed a pre-marked surface e.g. board, table, or floor, according to a set of rules (Sakilah, 2019).

A board race game is a fun game that is classified under the language board games category. It can be taught to practice the students' English especially vocabulary while enjoying some competitions (Kusumawati, 2017:115). Board Race game can be applied for students when we have just taught the lesson or we have taught the lesson last week (Sara, 2018:26). In the other situation, the game also can be played at the start of the class as icebreaking to get the students active and warm the students' brains. This is one of the great ways of testing what the students already know about the subject we are about to teach.

This kinesthetic activity is the way to get our class up and out of the students' seats. So they will not feel bored and sleepy in class. The activity is worked well in all ages of groups whether with young students as well as with an adult. This is best played with 6 students or more. The principle is the more students will be the better. All we need a whiteboard, two different colors of markers, and free space to move in the class. So, before beginning the game and starting the activity, the teacher should make sure that there is enough room to move around and clear out any obstructions that could get in the way.

Below are the general steps of playing the game according to Deubelbeiss (2019) and Ma'arif: 
1. As we see picture 1 below, the teacher will split the class into two teams and give each team a colored marker. If the class is a big size, it may be better to split the students into teams of 3 or 4 .

2. The teacher will draw a vertical line in the middle of the board and write a topic at the top of the board.

3. The students must then write as many words as the teacher requires related to the topic in the form of a relay race.

4. Each team wins one point for each correct word. Any words that are unreadable or misspelled are not counted. However, because this game is for assessing the students, so the assessment is more for each student even though they are divided in groups.

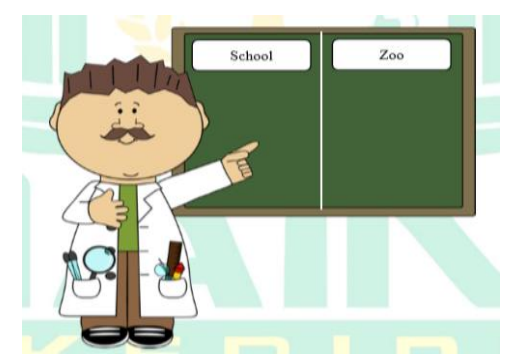

Picture 1. The example of topic in race word game

\section{METHODOLOGY}

As the aim of the research is to know the effectiveness of using the Board-Race game in teaching vocabulary, the researchers conducted an experiment that consists of a pre-test, treatment, and post-test. The pre-test and post-test were given to take the score of the student's achievement before and after being taught using the Board-Race game.

The researchers use the experimental and control group. The experimental design is based on Suharsini Arikunto (2001:84) that consists of a pre-test, treatment, and posttest. The researchers also wrote the instructional design, prepared 20 numbers of multiple choice and 20 essays for pre-test and post-test. The instructional and demonstration were given to the students before treatment or implementation to make them understand.

The students were given pre-test in the first meeting, treatment 4 times in the second, third, fourth, and fifth meeting, then after four meetings of treatment, the students were given post-test in the sixth meeting by using the same question in the previous test with a randomized number of questions.

Each meeting would be completed in 90 minutes. The allocation was 15 minutes for opening the class, 45 minutes for playing the game (10 minutes for preparation, 20 minutes for competition, 15 minutes for discussing the game/ material), 10 for free talking (asking and answering session all about difficulties in learning English), 10 minutes for giving an explanation about the next meeting, and 10 minutes for closing.

The population of this research was the second-grade students of Tsanawiyah Babul Khaer Bulukumba in the academic year 2018/2019. There were 30 students as the sample that was found by using purposive sampling. The data from this research was students score from the series of the test (pre and post-test).

The steps of the treatment as follow: 
a. First, to start the board race, the researchers explained to the class what is board race and the purpose of the game. The researchers tried to explain by making a diagram or some note inboard to demonstrate it.

b. Second, the researchers picked a couple of volunteers from the class to "race" against each other. Then asking two students came to stand behind me at the front of the class near the board. The researchers had two different colored markers which one color for each student.

c. Third, the researchers gave two different balanced themes and the group should race to write all vocabulary related to their individual theme.

d. Fourth, after giving a theme or topic, the researchers threw the markers to the other end of the classroom. and "Shout, "Go!" or something to start the race. The goal of a board race game is to have two people "race" from one end of the classroom to the board at the other end of the classroom and write the vocabulary related theme on the board.

e. Fifth, the students run to get their markers, touched the wall and had to run back to the board to write one vocabulary in his/ her mind.

f. Sixth, the first student to the board could get a "bonus" point for being fast. However, the first student who completes writing the correct answer could be awarded two points.

g. Seventh, after the demonstration, the researchers divided the class into two teams and began the board race competition. Every student should have a chance to race a student from the other team. The game allowed to test the students on a variety of topics/ themes while getting them fully engaged in the activity with some friendly "athletic" competition.

h. Lastly, the researchers awarded the winning team a prize and explained any difficulties that they had during the activity.

After the treatment, the data were analyzed by using SPSS .... The researchers would like to see the effect of the board race game by seeing the classification of the test and found the mean score as well as the gain between pre and post test.

\section{FINDINGS \& DISCUSSION}

\section{a. Pre Test}

The first step of the research was the researchers chose 2 classes, they were experimental class and control class. The pre-test was given by the researchers at the beginning of meeting in those two classes to know the students' vocabulary mastery related to the material that will be taught.

There were four topics were given in four meetings. They were something related to teacher (noun), something related to study (verb), something related to doctor (noun) and something related to hobby (noun).

The researchers found that control class got $30 \%$ fair category, 46, $67 \%$ for poor and $23,33 \%$ who got very poor category. While, the experimental class got nearly the same with control class $67 \%$ who got poor category and $33 \%$ who got very poor and both of class none in good and very good categories. Based on the data above that control and experimental class had the same stage of knowledge, it was proved by the diagram below: 


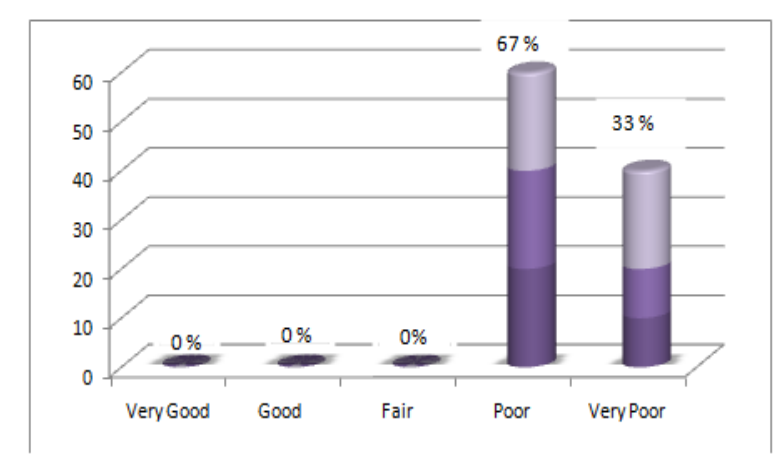

Picture 2. Diagram of students' pre test score in experimental class

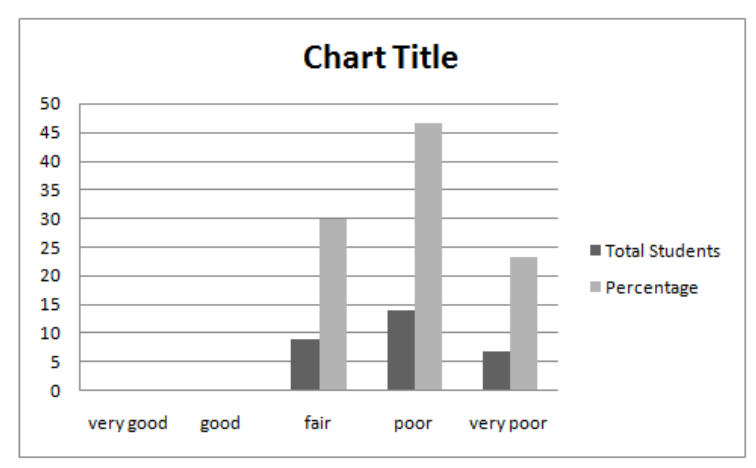

Picture 3. Diagram of students' pre test score in control class

Based on the pre-test, the control class got 46,67 mean score and experimental class got 30,47 which means control class was better than experimental class.

\section{b. Treatment}

The second step was giving treatment to the experimental class. The researchers gave 4 different topics in the implementation of treatment. The students were divided into two teams where they would like to race for winning the game only in 20 minutes. Besides increasing the students' vocabulary mastery as the main purpose of this game, the students were expected to have good cooperativeness and fast movement and also critical thinking.

In the first meeting of treatment, the researchers gave the word "doctor" for group A and "teacher" for group B. In this meeting, there were a lot of mistakes were done by the students like miss writing of some vocabularies related to the topic for example "medicin" that should be "medicine", "ilness" that should be "illness", "sergery" which should be "surgery". The mistake done by group B, such as "calk" should be "chalk" and "uniqeform" should be "uniform". Besides, the students lack vocabulary in the 10th and 15th minutes. They did not use the opportunity well that might result from a lack of cohesiveness between the members of groups or they have run out of vocabulary.

In the second meeting of the treatment, the researcher gave different topics with the first meeting, something about "Hobby" for Group A and something about "study" for 
group B. In the second meeting, there were some miswriting of some words done by both of group, such as "swimming" should be "swimming" for group A and "dencing" should be "dancing", and so on. Besides, the students still lack vocabulary in which they could not explore the new vocabulary. However, this meeting was better than before. The member showed improvement by having more cooperativeness among the members.

In the third meeting, the students were still with their group. In this meeting, the researcher distributed two topics that were the same as the first meeting but group A got the topic given to group B at the first meeting and vice versa. So, group A would improve the vocabulary related to "teacher" and group B for "doctor". At this time, the students could build good teamwork, they could fix their miss writing but there was still a little mistake in writing vocabulary. In the third meeting, they could write new vocabulary better than before.

In the last meeting, the researcher gave 2 topics which were given in the second meeting which group A was found "study" and group B was found "hobby". In this meeting the researchers look the students could improve their vocabularies, they could explore new vocabularies and they could reduce miswriting even, still a little bit miswriting.

\section{c. Post Test}

After giving treatment, the researchers did the test again. The researchers gave the post-test after the treatment for both two classes, control class that has been given a worksheet and experimental class to know the effectiveness of the Board Race Game. The result of the post-test can be shown from the tables below:

Tabel 1. Table of students' post test score in experimental class

\begin{tabular}{ccccc}
\hline \multicolumn{2}{c}{ No Classifcation Score } & $\begin{array}{c}\text { Prequenc Percentag } \\
\text { Post test }\end{array}$ \\
& & & e \\
\hline $\mathbf{1}$ & Very Good & $90-$ & 0 & 0 \\
& & 100 & & \\
$\mathbf{2}$ & Good & $70-89$ & 26 & 87 \\
$\mathbf{3}$ & Fair & $50-69$ & 4 & 13 \\
$\mathbf{4}$ & Poor & $30-49$ & 0 & 0 \\
$\mathbf{5}$ & Very Poor & $10-29$ & 0 & 0 \\
\hline & Total & & 30 & $100 \%$ \\
\hline
\end{tabular}

The above table shows that $87 \%$ of students were in a good category while $13 \%$ of students of the total $100 \%$ were in a fair category. The result of the post-test increased significantly. 
Tabel 2. Students' score in pre-test and post test of experimental class

\begin{tabular}{llll}
\hline Componen & Pre-test & Post-test & Gain \\
Mean & 30,46 & 78,2 & 47,73 \\
\hline
\end{tabular}

Table 2 shows us the score for the experimental class was 30,46 for pre-test and 78,2 post-test. It means the gain of both of the tests is 47,73 . Based on the data there is significant differentiation between pre-test and post-test which indicates that the use of board race games is useful and effective for English teaching especially for students in Junior High School level. As Octaviani, Handayani, \& Hamer (2019) found board race game is significantly increase student's vocabulary.

Tabel 3. Table of students' post test score in control class

\begin{tabular}{ccccc}
\hline \multirow{2}{*}{ No Classifcation Score } & \multicolumn{2}{c}{ Post test } \\
& Frequency & Percentage \\
\hline $\mathbf{1}$ & Very Good & $90-$ & 0 & 0 \\
& & 100 & & \\
$\mathbf{2}$ & Good & $70-89$ & 2 & 6,90 \\
$\mathbf{3}$ & Fair & $50-69$ & 15 & 51,72 \\
$\mathbf{4}$ & Poor & $30-49$ & 10 & 34,48 \\
$\mathbf{5}$ & Very Poor & $10-29$ & 2 & 06,90 \\
\hline & Total & 30 & $100 \%$ \\
\hline
\end{tabular}

The table of the students' post-test score in the control class shows that $6,90 \%$ of students were in a good category, $51,72 \%$ of students were in a fair category, $34,48 \%$ of students were in the poor category, and 0,69 students were in the very poor category. According to the data, the result of the post-test after doing worksheets did not increase significantly. It is proved by seeing the gain between pre and post-test.

Tabel 4. Students' score in pre-test and post test of control class

\begin{tabular}{llll}
\hline Componen & Pre-test & Post-test & Gain \\
Mean & 36,33 & 50,2 & 13,87 \\
\hline
\end{tabular}

In the control class, the mean score of the pre-test was 36,3. While in the post where the students were given worksheets, the mean score was 50,2. So, the gain both of the tests was 13,87 .

The above data shows us that the class that received the treatment experienced a more significant improvement than the one that did not. This reality supports Kususmawati's statement (2017). She says that learning process for the students which uses board race game and conventional method is different. It can be said that by applying two methods could give the different result in mastering vocabulary. So, it gives us a fact that using board race game can give significant influence in mastering vocabulary (Kusumawati, 2017). Many surveys also 
proved that the games have a positive and effective influence on the learning of foreign languages (Klimova, 2015: 1158 as cited in Sakilah, 2019).

\section{CONCLUSION}

Vocabulary is the heart and the basic unit of the language. Without vocabulary, no language could produce even speaking, listening, reading, and writing. Someone can visit one country without grammar knowledge, but he/ she can not do it without vocabulary. So, mastering vocabulary is a necessity. It is the basic step in learning the language.

However, mastering vocabulary is not as simple as we thought. It does not only talk about memorizing the words. it is the complicated process that needs the ability to know the words, to recall them at will, spell and use them correctly. So, we have to understand how they will be used in a meaningful context.

As it is difficult to learn vocabulary, the teacher should also be careful and keep the principle to teach the vocabulary. They have to select the words that will be given to the students. Secondly, the teachers must decide on what is involved in vocabulary learning, then pay attention to the quantity of vocabulary to be learned. Teachers have to avoid giving the students too many vocabulary because it will make them confusing. Thus, they should teach vocabulary based on daily activities to make them familiar and easy to use it.

Teachers must also create a creativity exercise to stimulate the students interesting in learning English, especially to fresh their minds to be ready in memorizing and remembering some vocabulary. In this paper, the researchers propose a board race game. A board race game is one of the kinesthetic games that has a benefit in the learning process which can be used in the process of teaching and learning activities. This is an educational game that can create a fun atmosphere in the classroom.

After doing the research in 6 weeks (one week for pre-test, four weeks for treatment, and the rest one week for post-test), the found this kinesthetic game was successfully to create a fun atmosphere in the teaching and learning process and increase the students' mastery of vocabulary. It is proved by the score of the pre-test was 30,46 and the posttest was 78,2 where the gain of both tests was 47,73. So, it is suggested to use board race game as the alternative media in teaching English.

\section{REFERENCE}

Boeker, M., Andel, P., Vach, W., \& Frankenschmidt, A. (2013). Game-based elearning is more effective than a conventional instructional method: a randomized controlled trial with third-year medical students. PloS one, 8(12). 1-9.

Fansury, A. H., \& Januarty, R. (2017). Model Pembelajaran Picture and Picture Dengan Media Games Android Dalam Meningkatkan Kemampuan Kosa Kata Siswa Kelas VII SMPN 35 Makassar. Jurnal. 
Kusumawati, F. P. (2017). Board race to boost students' vocabulary mastery. In Proceedings of INACELT (International Conference on English Language Teaching). 1 (1), pp. 113-120.

Octaviani, R., Handayani, I., \& Hamer, W. (2019). Applying Board Race Game to Increase Students' Vocabulary Mastery in Uttayan Suksa Krabi School, Thailand. Journal of English Education Studies, 2(2), 101-110.

Sakila, N. J. (2019). The Effectiveness of Using Board Race Game to Enhance Students' Vocabulary Mastery in Teaching English Concrete Noun (Bachelor Thesis), IAIN Salatiga, Indonesia

Sara, F. R. (2018). Improving Students' Vocabulary Through "Board Race" Language Game (The case of Second Year LMD Students at Larbi Ben M'Hidi University Oum EL Bouaghi (Magister Thesis), Larbi Ben M'hidi University-Oum El Bouaghi, Algeria.

Sari, E. P. (2014). Pengembangan Tes Formatif Berbasis Game pada Perangkat Bergerak untuk Kompetensi Dasar Menganalisis Hubungan Antara Gaya, Massa, dan Gerakan Benda pada Gerak Lurus bagi Siswa Sma (Magister Thesis), Universitas Negeri Malang, Indonesia.

Schmitt, N. (2010). Researching Vocabulary: A Vocabulary Research Manual. New York: Palgrave Macmillan.

Syamsinar, R., Bisse, N., \& Syamsu. (2019). Team Race Game in Teaching Vocabulary Mastery at Smp Negeri 2 Panca Rijang. La Ogi: English Language Journal, 6(1), 22-27.

Tedjasaputra, M. S. (2001). Bermain, Mainan, dan Permainan. Jakarta: Gramedia Wallace, M. J. (1982). Teaching Vocabulary. London: Heinemann 